\title{
EFFECTIVENESS OF LAWS TO COMBAT AUTOMOBILE POLLUTION: A LEGAL OVERVIEW
}

Prashant Bhadu, (Assistant Prof.)

Andaman Law College, Port-Blair (India)-744101

ORCID: https://orcid.org/0000-0002-4594-4537

Email: prashant.bhadu@gmail.com

Electronic version

URL: http://www.researchambition.com

DOI: https://doi.org/10.53724/ambition/v6n2.03

ISSN: 2456-0146

Vol. 6, Issue-II, August 2021

Page No. 09 - 16

Publisher

Welfare Universe

Electronic reference/Article is to be Cited:

Prashant Bhadu, (2021). Effectiveness Of Laws To Combat Automobile Pollution: A Legal Overview. Research Ambition: An International Multidisciplinary e-Journal, ISSN 2456-0146, 6(II), 09-16. https://doi.org/10.53724/ambition/v6n2.03

CResearch Ambition: An International Multidisciplinary e-Journal 2021. This Open Access article is published under a Creative Commons Attribution Non-Commercial 4.0 International License https://creativecommons.org/licenses/by-nc/4.0/, which permits non-commercial reuse, distribution, and reproduction in any medium, provided the original work is properly cited. For citation use the DOI. For commercial re-use, please contact editor email:- publish2017@ gmail.com By accessing the work you hereby accept the Terms. Non-commercial uses of the work are permitted without any further permission from Research Ambition: An International Multidisciplinary eJournal provided the work is properly attributed.

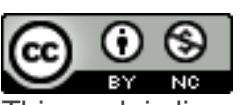

This work is licensed under a Creative Commons Attribution-NonCommercial 4.0 International License. 


\title{
EFFECTIVENESS OF LAWS TO COMBAT AUTOMOBILE POLLUTION: A LEGAL OVERVIEW
}

Prashant Bhadu, (Assistant Prof.)

Andaman Law College, Port-Blair (India)-744101

ORCID: https://orcid.org/0000-0002-4594-4537

Email: prashant.bhadu@gmail.com

\begin{abstract}
In a country whose economy is strong, the number of vehicles on the roads is bound to increase. The increasing number of vehicles on the roads should be considered as a necessary evil. The problem of automobile pollution seriously harms the air quality and ultimately becomes a serious threat to human life. An attempt has been made to highlight the various measures taken by the government for pollution control and the commendable effort of the judiciary through this research paper. In addition, new emission standards, problems related to their implementation and future roadmap with alternative fuels and changes needed for better control of automobile pollution hazard are also discussed.
\end{abstract}

Keywords: Air Pollution, Water Pollution, Automobile Pollution, Effectiveness of Laws, PIL, Indian Constitution and Indian Judiciary.

\section{Introduction}

Air pollution is becoming a matter of great concern in the last few years. All the countries of the world are facing this problem, because it is a huge threat to the environment as well as human health and life. Many factors are responsible for the decline in natural air quality, such as the burning of fossil fuels for transportation and manufacturing processes, agricultural activities, mining, toxic fumes from factories and other wastes, etc. These man-made artificial activities release pollutants into the atmosphere and which unbalance the natural combination of gases present in the atmosphere. There are two types of pollutants: Primary pollutants directly damage the air quality whereas secondary pollution is caused by mixing of primary pollutants with gases which later react chemically to form secondary pollutants. However, the primary concern expressed in this research paper is the pollution caused by transportation, which is called automobile pollution.

As civilization has developed and with the advancement of technology, the number of vehicles on the roads has increased rapidly. The smoke from burning fuel in the engine of vehicles mixes with air particles to form other toxic gases. In urban areas-in both developing and developed countries, it is mainly mobile or automobile pollution that contributes to the overall air quality problem. The number of vehicles has increased rapidly with the population of the country. The Delhi Economic Survey shows an increase of 135.59 percent in the number of vehicles between 1999-2000 and 2011-2012. The number of vehicles in 1999-2000 was 31.64 lakh, while it increased to 74.53 lakh in 2011-12. During the same period, the population of Delhi has increased by only 24 percent [from 1,34,50,827 to $1,67,53,235]$ and 
the road length by only 14 percent [from $22,000 \mathrm{~km}$ to $25,000 \mathrm{~km}$ ] respectively. ${ }^{1}$ The situation is similar in India and cities in other developing countries of the world. This indicates the need to control automobile pollution.

In Delhi, data shows that of the total 3,000 metric tones' of pollutants released every day, two-thirds [66 percent] are from vehicles. Similarly, the contribution of vehicles to urban air pollution is 52 percent in Bombay and close to one-third in Calcutta. ${ }^{2}$

The most dangerous aspect of automobile pollution is that pollutants are released and persist at the level at which we breathe in the air, posing a far greater threat to human health than chimney smoke. The major pollutants released by the burning of fuel in automobile are as follows:

1) Ozone [03]: Nitrogen in sunlight is formed due to a chemical reaction between oxides and hydrocarbons, which are released due to the combustion of fuel. Known to be responsible for causing respiratory problems, it is also primarily responsible for the formation of haze.

2) Particulate matter [PM]: Other major contributors to smog include soot particles, metals, and pollen. These are very fine particles that are very harmful to human health due to their deep penetration into the lungs.

3) Nitrogen oxides [NOx]: Automobile pollutants can irritate the lungs and weaken the body's defences against respiratory infections such as pneumonia and influenza. In addition, they aid in the formation of ozone and particulate matter. In addition, they assist in the formation of ozone and particulate matter.

4) Carbon monoxide [CO]: When inhaled, $\mathrm{CO}$ blocks the transport of oxygen to the brain, heart, and other vital organs in the human body. Newborn children and people with chronic illnesses are especially susceptible to the effects of $\mathrm{CO}$.

5) Sulfur dioxide [SO2]: Sulfur, formed due to the burning of automobile fuels, is mainly caused by the burning of diesel. It can react in the environment to form fine particulates and pose a health risk to young children and asthmatics.

6) Hazardous air pollutants [toxics]: These chemical compounds, which are emitted by cars, trucks, refineries, gas pumps, and related sources, have been linked to birth defects, cancer, and other serious illnesses.

\section{Causes of Automobile Pollution}

Following are the major causes of automobile pollution:

1) Traffic Congestions: In most urban cities, the number of motor vehicles is high and so does the traffic congestion. When many of these vehicles congest the same area, emissions per kilometre increase, contributing to automobile pollution.

2) Technical Issues with Gasoline Engines: There are many problems with gasoline engines that can result in automobile pollution. For example, evaporative emissions occur when fuel enters the atmosphere after evaporating from a fuel tank or carburetor. Also, in four-stroke gasoline engines, if the combustible fuel and air-fuel mixture from the carburetor exit the piston rings, enter the crankcase and then leak into the atmosphere through the vents, the crankcase blow-by happens.

3) Vehicle Population: Over the past few decades, vehicles have been produced a lot. The motor vehicle population is projected to reach 1.1 billion in 2020, with Europe and the United States accounting for

\footnotetext{
${ }^{1}$ The Delhi Economic Survey, 2013, http://delhiplanning.nic.in/content/economic-survey-delhi-2012-2013, last visited on 29th June, 2021.

${ }^{2}$ 2nd ARC Report, 5th August, 2005, https://en.wikipedia.org/wiki/Administrative_Reforms_Commission, last visited on 29th June, 2021. 
nearly two-thirds of the world's vehicle population. This rapid increase in the number of vehicles in the world means that more gas is combusted, leading to more emissions and increased air pollution.

4) Gasoline Itself: Vehicles rely on gasoline for mechanical movement. However, gasoline is made up of hydrogen and carbon atoms, which together form the hydrocarbons, which form gasoline and diesel. It means that no matter what happens, particles or compounds of carbon and nitrogen will be released into the atmosphere as soon as the gasoline is combusted, regardless of the engine.

5) Combustion Process: When complete combustion occurs, the oxygen converts all the hydrogen in the gasoline to water and the carbon-to-carbon dioxide. Not only this, vehicles also emit other pollutants, which pollute the air with harmful effects especially for humans and the environment. The combustion process emits carbon monoxide, nitrogen oxides, hydrocarbons, sulfur dioxide, carbon dioxide and particulate matter, which are harmful to the environment. Particulate matter is responsible for about 30,000 premature deaths annually.

\section{Laws relating to Combat Automobile Pollution}

The following laws have been passed and enforced by the Indian Parliament to deal with automobile pollution:

a) The Air [Prevention and Control of Pollution] Act, 1981: Section 20 of the Act gives power to make directions for ensuring the standards of emission from automobiles. With a view to ensuring that the standards for emission of air pollutants from automobiles are prescribed by the State Board under Clause [g] of sub-section. Sub-section [1] of Section 17 are complied with, the State Government shall, in consultation with the State Board, give such instructions as may be deemed neces $\neg$ sary to the concerned authority in charge of registration of motor vehicles under the Motor Vehicles Act, 1939, and such authority shall, notwithstanding anything contained in that Act or the rules made thereunder be bound to comply with such instructions. The Motor Vehicles Act, 1988, inter alia, provides for prevention and control of air pollution from automobiles which constitute a major source of pollution everywhere, especially in the congested metropolis. Sub-section [1] of Section 110 of the said Act inter alia lays down that the Central Government may make rules regulating the construction, equipment and maintenance of motor vehicles and trailers with respect to all or any of the following matters: [i] the emission of smoke, visible vapour, sparks, ashes, grit or oil; [ii] the reduction of noise emitted by or caused by vehicles; [iii] standards for emission of air pollutants.

b) The Environment [Protection] Act, 1986: Section 3[1] of the Act empowers the Central Government to take all necessary measures aimed at protecting and improving the quality of the environment and preventing, controlling and reducing environmental pollution.

c) The Motor Vehicle Act, 1989: the amendments made to the Act in 1994 encouraged the use of CNG as a fuel and relaxation of incentive permits or fixation of fares by the state government. In the year 2000 saw a welcome changes in the amendment which authorized the use of LPG as an automotive fuel.

d) The Central Motor Vehicles Rules, 1989: Rules 115 and 116 regarding compliance of certain standard of air pollution by vehicles and measurement of pollutants emitted from motor vehicles.

\section{Role of Judiciary in Combat Automobile Pollution}

The Apex Court has accepted the right to live in a healthy environment as a fundamental right under Article 21 of the Indian Constitution. Rural Litigation and Entitlement Kendra v. State of Uttar 
Pradesh $^{3}$ was one of the first cases where the Apex Court dealt with issues related to environment and ecological balance. The link between the quality of the environment and the right to life was addressed by a constitutional Bench of the Apex Court in Charan Lal Sahu v. Union of India. ${ }^{4}$ Similarly, in Subash Kumar v. State of Bihar" the Court observed that "right to life guaranteed by article 21 includes the right of enjoyment of pollution-free water and air for full enjoyment of life". Through this case, the Court recognized the right to a healthy environment as part of the fundamental right to life.

One of the earliest cases relating to automobile pollution was Murli Purushottam v. Union of India ${ }^{6}$ where the petitioner focused on the consequences of air pollution generated through uncontrolled and non-stop automobile spitting and urged the Court to issue appropriate directions to the authorities concerned. The Court directed the state government to take appropriate steps regarding the implementation of Rule 115 and Rule 116 of the Central Motor Vehicles Rules, 1989 and expedite the process of installing necessary equipment for monitoring of air quality.

In Ajay Singh Rawat v. Union of India, ${ }^{7}$ the Apex Court directed that vehicular movement caused a lot of air pollution due to heavy vehicles plying on the Mall Road and bridge paths, this polluted air eventually settles in the Nainital Lake catchment area. The Supreme Court of India took note of this and called for an end to the plying of heavy vehicles, finding it necessary to restore the natural beauty and prevent soil pollution.

A Public Interest Litigation was filed by environmentalist Mr. M.C. Mehta in the Supreme Court of India in 1958 concerned with uncontrolled pollution and its devastating effects on the people of Delhi. ${ }^{8}$ The appeal remained dormant for many years, except for the formation of a few fact-finding commissions. However, in 1996, the Apex Court ordered all government vehicles to be converted to CNG. ${ }^{9}$ In 1998 , the Court passed an order which said that all buses should be converted from diesel fuel engines to CNG by March 31, 2001. In 2002, the Apex Court reaffirmed its decision on CNG conversion and passed strict orders to government agencies for its implementation. ${ }^{10}$ The various orders passed by the Supreme Court can be summarized as follows:

a) Movement of goods vehicles was banned during day time and orders were passed to strictly implement it.

b) The use and sale of leaded petrol was banned.

c) The old commercial and transport vehicles were ordered to be phased out.

d) Restrictions on the use of $2 \mathrm{~T}$ oil.

e) Two-stroke engines were one of the biggest contributors to air pollution and so it was ordered that only pre-mixed petrol be made available to them.

f) Two independent fuel testing laboratories were to be set-up for non-commercial vehicles and later Euro-II was made mandatory by April 1, 2000.

g) The Transport Department was ordered to set-up facilities for inspection and maintenance of old vehicles.

3. AIR 1985 SC 652

4. AIR 1990 SC 1480

5. AIR 1991 SC 420

6. AIR 1993 Ker 297.

7. [1995] 3 SCC 266.

${ }^{8}$. WP [Civil] No. 13029 of 1985.

9 . Order dated $26^{\text {th }}$ April, 1996.

${ }^{10}$. Order dated $5^{\text {th }}$ April, 2002. 
h) New ISBTs were ordered to be set-up at the north and south-west borders to avoid pollution caused by inter-state buses.

i) Expansion of CNG outlets and expansion of public transport system to 10000 buses.

\section{Emission Norms in India}

The first emission norms in India existed long before 1989 but came into effect for the first time in 1989. They were then replaced by a new set of rules dealing with petrol emissions in 1991 and diesel emissions in 1992. In the 1990s-2000s, these rules were made stricter and their implementation was made strict. Most automakers had to incorporate technology upgrades such as catalytic converters to reduce exhaust emissions. This necessitated the use of lead-free and low-sulfur fuels. Initially, refineries were deputed to supply lead-free gasoline to the NCR and major cities and later to the rest of the country. Since the year 2000 we have shifted to European emission standards for 4-wheel vehicles, both light duty and heavy duty. These criteria are known as Euro-I and Euro-II norms. However, we have our own emission norms for 2-wheel vehicles and 3-wheel vehicles known as Bharat Stage I and Stage II norms. ${ }^{11}$ The following tables show the increase in emission norms with respect to pollutant levels:

Table 1: Emission norms for passenger cars

\begin{tabular}{|l|l|l|}
\hline Norms & $\mathbf{C O}(\mathbf{g} / \mathbf{k m})$ & HC + NOx $\mathbf{~ g / k m})$ \\
\hline 1991 Norms & $14.3-27.1$ & $2.0[$ only HC] \\
\hline 1996 Norms & $8.68-12.40$ & $3.00-4.36$ \\
\hline 1998 Norms & $4.34-6.20$ & $1.50-2.18$ \\
\hline India Stage 2000 norms & 2.72 & 0.97 \\
\hline Bharat Stage-II & 2.2 & 0.5 \\
\hline Bharat Stage-IV & 2.3 & $0.35[$ combined] \\
\hline Bharat Stage-IV & 1.0 & $0.18[$ combined] \\
\hline
\end{tabular}

Table 2: Emission Norms for 2-3 wheelers

\begin{tabular}{|l|l|l|}
\hline Norms & $\mathbf{C O}(\mathbf{g} / \mathbf{k m})$ & $\mathbf{H C}+\mathbf{N O x} \mathbf{( g / k m})$ \\
\hline 1991 Norms & $12-30$ & $8-12$ \\
\hline 1996 Norms & 4.5 & 3.6 \\
\hline India Stage 2000 norms & 2.0 & 2.0 \\
\hline Bharat Stage--II & 1.6 & 1.5 \\
\hline Bharat Stage-III & 1.0 & 1.0 \\
\hline
\end{tabular}

\section{National Auto Fuel Policy}

The 2003 Auto Fuel Policy harmonized many of India's vehicle regulations with those of Europe and adopted a roadmap for progressively stricter fuel quality and vehicle emissions standards through 2010.

A roadmap was drawn-up for fuel standards/emission norms for new vehicles with four or more wheels. Bharat Stage-II fuel/emission norms were implemented with effect from April 1, 2005. Fuel/emission norms equivalent to Euro-III were made mandatory w.e.f. April 1, 2010. In addition, Euro-IV norms were made mandatory for all private vehicles for eleven major cities.

Table 3: Indian Emission Standards [4-Wheel Vehicles)

\begin{tabular}{|l|l|l|l|}
\hline Standard & Reference & Date & Region \\
\hline India 2000 & Euro-I & 2000 & Nationwide \\
\hline Bharat Stage-II & Euro-II & 2001 & NCR, Mumbai, Kolkata, Chennai \\
\hline & & 04.2003 & NCR, 11 Cities \\
\hline
\end{tabular}

11 . M.C. Mehta v. Union of India, Order dated April 4, 1999. 


\begin{tabular}{|l|l|l|l|}
\hline & & 04.2005 & Nationwide \\
\hline Bharat Stage-III & Euro-III & 04.2005 & NCR, 11 Cities \\
\hline & & 04.2010 & Nationwide \\
\hline Bharat Stage IV & Euro-IV & 04.2010 & NCR, 13 Cities \\
\hline
\end{tabular}

Mumbai, Kolkata, Chennai, Bangalore, Hyderabad, Secunderabad, Ahmedabad, Pune, Surat, Kanpur and Agra. Above cities plus Solapur and Lucknow. The program was later expanded with the aim of including 50 additional cities by March, 2015.

These standards mentioned above are applicable to all 4-wheel vehicles in the area mentioned therein and in addition the National Auto Fuel Policy, 2003 has also introduced some additional requirements for interstate buses originating from Delhi or other mentioned cities or ends.

Bharat stage-II standards was implemented from April 1, 2005 for all two-and three-wheel vehicles and subsequently Bharat stage-III standards were incorporated from April 1, 2010 across the country. However, Bharat stage-IV standards could not be implemented across the country and implementation was delayed due to various reasons. One of the main reasons was inefficiency and lack of confidence and enthusiasm among fuel producers to produce fuels that meet the standards prescribed by Bharat stage-IV i.e., 50ppm sulfur containing fuel.

The Planning Commission of India had set-up a committee under the chairmanship of Dr. Soumitra Choudhary in 2013 to draft an updated Auto Fuel Policy for India ${ }^{12}$ to implement Bharat stage-IV standards across the country. The committee recommended that Bharat stage-IV should be fully implemented across the country by 2017. The panel also recommended further upgradation of Bharat stage $-\mathrm{V}$ standards by April, 2020. Suggestions were made to issue Bharat stage-IV+ standard [40ppm sulpur] before India stage$\mathrm{V}$ is implemented.

\section{Fuel Economy Standards}

The better the fuel economy of a vehicle - the lower the $\mathrm{CO} 2$ emissions. The norm is calculated based on the Corporate Average Fuel Consumption [CAFC] system. Vehicle fuel consumption is calculated by multiplying the $\mathrm{CO} 2[\mathrm{~g} / \mathrm{km}]$ measured over the NEDC emissions test cycle by a factor dependent on the vehicle's fuel type. For vehicles using diesel, LPG or CNG, another factor is used to convert fuel consumption to the equivalent of petrol. In simple words, it is the measure of $\mathrm{CO} 2$ produced by burning per volume of fuel. ${ }^{13}$

Efforts to set fuel economy standards began in 2007. However, they were not produced due to interministerial conflicts and problems and pressure from the auto industry. However, they were not produced due to inter-ministerial conflicts and problems and pressure from the auto industry. The first set of minimum fuel efficiency norms for passenger vehicles was introduced in India in January 2014, two sets of standards were introduced. One for the year 2016-17 to 2020-21 and the other for 2021-22. These standards apply to petrol, diesel, and CNG and LPG vehicles with up to 9 seats and a GVW of $3500 \mathrm{~kg}$ or less. $^{14}$

The fuel efficiency requirements set by the recent government require a one-point improvement, which is roughly equivalent to the average fleet fuel efficiency which is $18.2 \mathrm{~km} /$ litter by $2020-21$ and $21 \mathrm{~km} / \mathrm{litter}$ further by 2025-26. These targets mean an annual improvement of 1.7 percent and 3.0 percent, respectively,

\footnotetext{
${ }^{12}$ National Auto Fuel Vision and Policy, 2025, https://climate-laws.org/geographies/india/policies/national-auto-fuel-policy-and-auto-fuelvision-and-policy-2025, last visited on 29th June, 2021.

13 Ibid.

${ }^{14}$ Ibid
} 
going forward. ${ }^{15}$

\section{Conclusion}

The primary reason for mandating stringent fuel and emissions standards, which reflects huge investment in refineries on the one hand and the automobile sector on the other, is a high concern for public health. It is true that deterioration in ambient air quality is not the only source of stress on the lives and health of our citizens. Nor are vehicular tailpipe emissions the only source of air-borne pollutants. However, vehicular emissions are actually a major contributor to air-borne pollution. And in trying to shape public policy in a way that protects human health from the diverse threats to modern life, it is important to address these issues one by one, separately and ultimately jointly. Evidence on emissions levels in the country shows that various steps taken in the past to limit emissions of air pollutants have resulted in a positive impact. But these efforts are being offset by increased urban density, in associated road transport and as a result of vehicular tailpipe emissions. As the country grows, people will continue to move away from agriculture as a mainstay of livelihood, urbanization will accelerate, disposable income will increase and with it the needs of urban transport will also increase.

It is important for the government to devise better policies to curb this menace in the performance of its constitutional duty under Article 48-A and at the same time it is up to us citizens to promote the use of clean modes of travel and encourage under our fundamental duty on the basis of Article 51-A.

$* * * * * * * * * * * * * * * * * * * * * * * * * * * * * * * *$

\footnotetext{
${ }^{15}$ National Auto Fuel Vision and Policy, 2025, https://climate-laws.org/geographies/india/policies/national-auto-fuel-policy-and-auto-fuel-
} vision-and-policy-2025, last visited on 29th June, 2021. 